\title{
AN ALTERNATIVE DIAGNOSTIC DESIGN FOR CHRONIC KIDNEY DISEASE DETECTION BASED ON CYSTATIN C
}

\author{
BJORN JOHN STEPHEN, DIGNYA DESAI, MANALI DATTA*
}

Amity Institute of Biotechnology, Amity University Rajasthan, Jaipur - 303 002, Rajasthan, India.

Email: mdatta@jpr.amity.edu

Received: 09 January 2017, Revised and Accepted: 31 January 2017

\section{ABSTRACT}

Objective: Chronic kidney disease (CKD) is usually diagnosed by measuring the glomerular filtration rate (GFR), and diagnostics are still inadequate at the clinical level. Most of the diagnostic kits available estimate GFR rate by determining clearance of serum creatinine using various instrumentation generally available at hospitals. Serum creatinine is considered the major marker for renal deficiency disorders. In addition, it is also an indicator of muscle mass and dietary intake. Hence, the need for a more reliable marker for CKD arises. A low molecular weight protein cystatin C has been found to be a reliable biomarker for the detection of kidney function as it is solely filtered by the glomerulus and not secreted by renal tubules.

Methods: The basic setup of the kit was designed using a syringe containing multiwalled carbon nanotube (MWCNT) conjugated protease. Casein beads were immersed in phosphate-buffered saline in the syringe. The glass/MWCNT/papain solid support was subsequently inserted into the syringe in such a way that the beads came in contact with the immobilized enzyme conjugate. The inhibitory action of cystatin $\mathrm{C}$ against protease forms the basis for the functioning of the kit.

Results: Results indicated that papain while immobilization needs to be in dynamic conformation. At $37^{\circ} \mathrm{C}$, papain gave better activity as compared to protein immobilized at $4^{\circ} \mathrm{C}$. Fourier transformation infrared spectroscopy observations confirmed the physical adsorption on the MWCNTs. The experimentation confirmed the feasibility of using prototype for detection of cystatin C.

Conclusion: The proposed alternate method may offer a cost effective solution to detection of CKD and its progression. Papain conjugated with MWCNT indicated its temperature and pH stability. The initial design of the diagnostic kit for the detection of CKD has shown to be successful with a good detection range corresponding to Stages I and II of CKD. Further testing needs to be done for the prototype using patient samples

Keywords: Chronic kidney disease, Diagnostic kit, Immobilized papain, Protease inhibitor.

(c) 2017 The Authors. Published by Innovare Academic Sciences Pvt Ltd. This is an open access article under the CC BY license (http://creativecommons. org/licenses/by/4. 0/) DOI: http://dx.doi.org/10.22159/ajpcr.2017.v10i4.17001

\section{INTRODUCTION}

Chronic kidney disease (CKD) is the fourth most common kidney disease behind kidney infection, kidney stone, and kidney cancer [1]. CKD along with acute kidney injury (AKI) is the two broad classifications of renal insufficiency, where CKD is characterized by the gradual loss of kidney function in contrast to AKI characterized by the sudden loss of kidney function [2]. This worldwide public health issue is estimated to affect 1 in every 10 adults in India, while it is estimated that about $11.6 \%$ of adults in the US have CKD with similar figures being reported in other countries as well $[3,4]$.

It is estimated that CKD-related deaths were pinned at 5.21 million in 2008 and is expected to rise to 7.63 million by 2020 [5]. Diabetes and high blood pressure are the two most common causes of CKD where diabetes accounts for $35 \%$ of all cases, while high blood pressure accounts for $30 \%$ of all CKD cases among other factors such as kidney stones, systemic lupus erythematosus, and polycystic kidney disease [6]. CKD is divided into five stages based on the severity of the disease, and the division is determined by the calculation of glomerular filtration rate (GFR). Based on the current available techniques, detection at early stage is limited to laboratory-based techniques, and hence, many cases are clinically unrecognized. Detection at early levels may provide candidates with preventive measures and enable control at early stages.

Over the years, many biomarkers such as creatinine, beta-trace proteinuric acid, and cystatin $\mathrm{C}$ have been discovered for the detection of CKD [7]. Creatinine, considered as a major biomarker, is also an indicator of loss in muscle mass, diet, race, and age. It also presents a blind spot, i.e., the kidney function has to stop functioning by $50 \%$ if it needs to be detected, thus posing a serious threat. Hence, there is a need for a more suitable marker, which would facilitate detection at earlier stages of CKD, thus preventing the severity of the disease to arise [8].

Cystatin C, a $13 \mathrm{kDa}$ cysteine protease inhibitor (PI), has been found to be solely filtered by renal tubules, and tubular malfunctioning will result in increase in urine cystatin C concentration (Fig. 1). The concentration of serum cystatin remains fairly constant irrespective of age and it lacks the "blind spot," thus making it a better biomarker than creatinine $[9,10]$.

There is a growing body of evidence that suggests that cystatin C can be used to detect kidney disease at earlier stages than serum creatinine [11], which may help facilitate prevention efforts in the elderly and those with diabetes, hypertension, or cardiovascular disease Till now, all the assays which have been developed for CKD require a hospital- and/or laboratory-based diagnosis (risk, injury, failure, loss of kidney function, and end-stage kidney disease analysis, GFR monitoring) for confirmation [12].

In this study, a novel diagnostic kit is being proposed for the detection of CKD based on the principle of interaction between cystatin $C$ and protease. A prototype uses two inhibitors against cysteine protease family, namely, cystatin C and antipain hydrochloride. The efficiency of the kit was tested using these inhibitors with enzyme conjugate multiwalled carbon nanotube (MWCNT) immobilized on a glass slide and casein beads used as substrate. 


\section{MATERIALS AND METHODS}

Materials

MWCNT, papain, 3-aminopropyltriethoxysilane (APTES), glutaraldehyde, cystatin C, and antipain dihydrochloride were procured from Sigma-Aldrich (India). Bradford reagent, sodium chloride, albumin, sodium carbonate, Folin-Ciocalteu reagent, tyrosine, 3\% trichloroacetic acid (TCA), sulfuric acid, and hydrogen peroxide were prepared according to the requirements.

\section{Setup of solid support: Immobilization of glass/MWCNT/papain}

Microscope glass slide (Axiva Sichem Biotech, New Delhi) was taken and cut into small rectangular shape of sizes $(1 \mathrm{~cm} \times 2 \mathrm{~cm})$. The slides were washed with ethanol and immersed in a Petri plate filled with piranha solution ( $3: 1$ solution of $\mathrm{H}_{2} \mathrm{SO}_{4}$ and $\mathrm{H}_{2} \mathrm{O}_{2}$ ) and incubated at $70^{\circ} \mathrm{C}$ for $1 \mathrm{hr}$. The slides were rinsed with water and dipped in $10 \%$ APTES and incubated overnight at room temperature (RT). The slides were dried. MWCNT was suspended in $10 \mathrm{ml}$ phosphate-buffered saline (PBS) solution and activated slides were incubated in the suspension with constant agitation. Each glass piece was immersed in $5 \mathrm{ml}(3 \mathrm{mg} / \mathrm{ml})$ of papain solution for $5 \mathrm{hrs}$ with constant agitation and stored at $4^{\circ} \mathrm{C}[13]$.

\section{Selection of substrate and enzyme}

Casein beads

$500 \mathrm{ml}$ milk was boiled in a beaker and $500 \mu \mathrm{l}-1 \mathrm{ml}$ of acetic acid was added. The precipitate was molded into beads $(0.5 \mathrm{~cm}$ in diameter $)$. Beads were dried and stored at RT [14].

\section{Protease activity assay}

The protease activity of papain was determined using casein according to Ding et al., 2003. Briefly, required amount of free and immobilized papain was taken and incubated with phosphate buffer solution $(5 \mathrm{ml}$, $\mathrm{pH} 7)$ and casein solution $(1 \mathrm{ml}, 0.5 \%)$ at $37^{\circ} \mathrm{C}$ for 30 minutes. TCA (300 $\mu \mathrm{l}, 3 \%)$ was added as a stopping reagent. Folin-Ciocalteu reagent was added and absorbance measured at $670 \mathrm{~nm}$. One unit of enzyme activity is defined as $1 \mu \mathrm{g}$ of tyrosine formed per minute at $37^{\circ} \mathrm{C}$ [15].

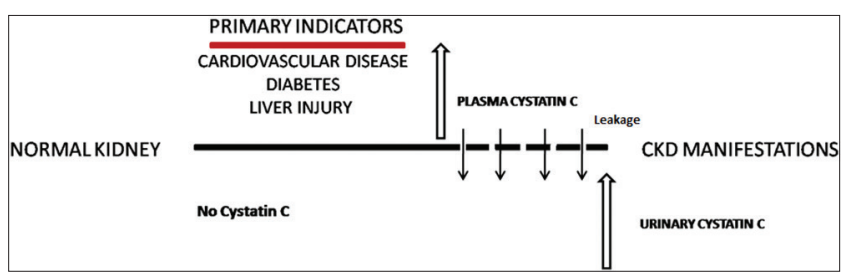

Fig. 1: Conditional indicators for the presence and absence of cystatin $\mathrm{C}$, a protein marker present in urine in symptomatic kidney malfunction. In case of normal kidney, no cystatin C will be present in the urine although primary disorders may lead to increased levels in the plasma

\section{Kinetic study of free and immobilized enzyme}

The effect of $\mathrm{pH}$ and temperature on the activity of the free and immobilized papain was evaluated. Papain activity after was measured over a range of $\mathrm{pH}$ 5-9. This was followed by monitoring the enzyme activity of papain in phosphate buffer solution $(3 \mathrm{mg} / \mathrm{ml}, \mathrm{pH} 7.5)$; solution was studied at varying temperature $\left(30-90^{\circ} \mathrm{C}\right)$. Thus, the optimum $\mathrm{pH}$ and temperature for optimal enzyme activity was determined.

\section{Actions of inhibitors of free and immobilized enzymes}

The action of cysteine PIs on papain was evaluated. Cysteine PIs such as antipain hydrochloride $(0.00005-0.008 \mathrm{mg} / \mathrm{ml})$ and cystatin $\mathrm{C}$ $(0.00005-0.008 \mathrm{mg} / \mathrm{ml})$ were tested against free and immobilized protease.

\section{Kit preparation}

The basic set up of the kit was designed using a syringe. Casein beads were immersed in $2 \mathrm{ml}$ of PBS in the syringe. The glass/MWCNT/papain solid support was subsequently inserted into the syringe in such a way that the beads came in contact with the immobilized enzyme conjugate. The setup was incubated for 30 minutes at RT, and the elute was tested for protease activity at $670 \mathrm{~nm}$. The same procedure was repeated in the presence of PIs (Fig. 2)

\section{RESULTS}

The measurement of cystatin C (Fig. 3) is based on the concept that when an individual suffers from initial stages of CKD, the filtration by the glomerulus is affected and cystatin $\mathrm{C}$ level rises in the urine. The amount of cystatin $\mathrm{C}$ in the urine will directly affect the protease which is immobilized on the solid support. Thus, the variation in the cystatin C will decide the amount of product catalyzed by papain, and hence, levels can be colorimetrically quantified. This difference in range was assumed to be able to be detected by the kit so that we can categorize if an individual is suffering from CKD or not.

\section{Standardization of substrate}

Albumin and casein are the most common substrate used for proteases. It was found that the reactivity of casein with papain gave better results as compared to albumin, hence our selection of substrate. As reusability and retrievability of substrate were important factors in kit development, casein beads were decided to be used. A slight decrease in enzymatic activity between the free and beaded casein was observed because of availability of surface of casein beads.

Preparation and standardization of the immobilized papain Immobilization of papain was carried to facilitate reusability of the enzyme. Immobilization of enzyme by physical adsorption was preferred over other methods. Immobilization of enzymes at $4^{\circ} \mathrm{C}$ was tested because it was at this temperature the enzyme solution remains inactive and stable in storage. Earlier studies indicated papain immobilization on metal chelating sepharose being carried out at RT, while that on macroporous polymer carrier, temperatures range from

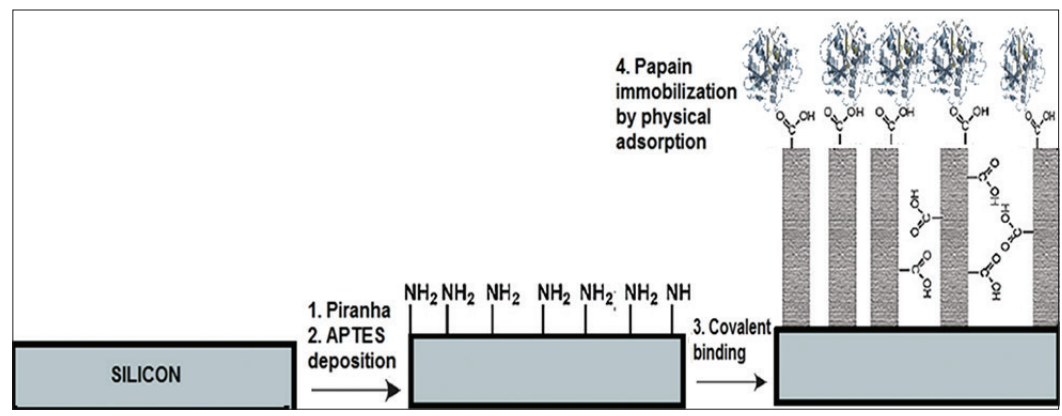

Fig. 2: Diagrammatic summary of setup of glass/multiwalled carbon nanotube (MWCNT)/papain. Template treated with piranha solution and 10\% 3-aminopropyltriethoxysilane. Slides loaded with MWCNT suspended in phosphate-buffered saline solution for $24 \mathrm{hrs}$ with constant agitation. Papain physically adsorbed on MWCNT glass pieces 
$0^{\circ} \mathrm{C}$ to $5^{\circ} \mathrm{C}$ [16]. However, immobilization of papain at $4^{\circ} \mathrm{C}$ gave less enzyme activity than enzyme immobilized at $37^{\circ} \mathrm{C}$. The finding may be supported by the fact that for enzymes to immobilize, the protein needs to be in dynamic conformation. In addition, it was observed that stability of enzyme increased at RT upon immobilization (Fig. 4a).

In a healthy individual, the $\mathrm{pH}$ of urine is between 6.0 and 7.0, while for patients suffering from CKD, the $\mathrm{pH}$ of urine is between 5.0 and 5.5 depending on the severity of the disease [17]. Thus, it was necessary to assess the prototype for its functionality for a variable $\mathrm{pH}$ range. Hence, the next step was the characterization studies of the enzyme where the effect of medium $\mathrm{pH}$ on the enzymatic activity of the immobilized and free papain was evaluated. The optimal $\mathrm{pH}$ of the free enzyme solution and immobilized enzyme was 7.5. There was a lack in the shift of optimum $\mathrm{pH}$ between free and immobilized papain, which were normally noticed in other experiments [15]. Considering the symptomatic $\mathrm{pH}$ for CKD (pH 5-5.5), the immobilized papain indicated a comparatively better activity (Fig. 4b).

In the case of MWCNT-papain, the effect of physical adsorption of papain on MWCNT was evaluated and immobilization process was successful with good enzymatic activity. The relative activity was found to be $75 \%$ as compared to free enzyme. Fourier transformation infrared (FTIR) was used to compare the bonding pattern between the MWCNT and MWCNT immobilized with papain. Both MWCNT-NH2 and papain immobilized onto MWCNT-NH2 have comparable characteristic peaks. A distinct peak could be observed at $1734 / \mathrm{cm}$, indicating the presence of ester bonds (Fig. 5). The amide bond represented by $-\mathrm{C}-\mathrm{N}$ $(\sim 1400 / \mathrm{cm}),-\mathrm{N}-\mathrm{H}$ amide stretch $(3700-3500 / \mathrm{cm})$, and $\mathrm{C}=0$ amide stretch $(1690-1630 / \mathrm{cm})[18]$ was not present in the spectra, and hence, it was hypothesized that the enzyme was physically adsorbed on the MWCNTs.

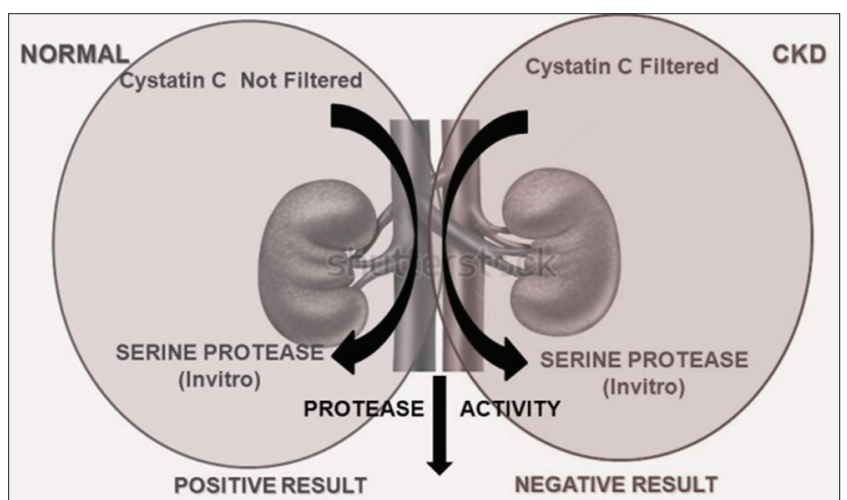

Fig. 3: Schematic representation of basic concept of kit. In norma kidney, cystatin $\mathrm{C}$ is filtered by the glomerulus as a result not secreted into the urine, thereby producing a positive result for protease activity due to the absence of cystatin $C$, a cysteine protease inhibitor (PI), while in patients suffering from chronic kidney disease, cystatin $\mathrm{C}$ leaks out the urine giving a negative result for protease activity due to the absence of PI (cystatin C)
Testing of prototype with PIs

As a prototype is being designed, the probability of the functionality needed to be tested. Hence, we selected inhibitors antipain hydrochloride and cystatin C for the experiment.

Antipain, a peptide isolated from actinomycetes, has also shown specific activity toward papain. An in silico study exhibited three structural motifs present in cystatins, namely, glycine residue at the N-terminus, QxVxG motif situated in the $\beta$-hairpin loop, and an aromatic residue on the $\beta$-hairpin loop enabled binding to active site residues of papain, namely, C25, H159, and N175 [19].

The next step was to identify the specificity and sensitivity of the diagnostic kit. Cystatin C levels found in the urine ranged from about 0.000052 to $0.0003 \mathrm{mg} / \mathrm{ml}$ in healthy individuals and 0.0005 to $0.0021 \mathrm{mg} / \mathrm{ml}$ for CKD patients [16]. For AKI, the level of cystatin C ranged from 0.0026 to $0.005 \mathrm{mg} / \mathrm{ml}$, while for kidney tubular dysfunction, the range of cystatin $\mathrm{C}$ level is much broader from 0.00046 to $0.008 \mathrm{mg} / \mathrm{ml} \mathrm{[17]}$.

For our test, the inhibitor concentrations were varied from 0.00005 to $0.008 \mathrm{mg} / \mathrm{ml}$. The relative activity for immobilized papain was monitored in the presence of inhibitors. The enzymatic activity in the absence of inhibitors $(0 \mathrm{mg} / \mathrm{ml})$ was considered to be $100 \%$. The Stage I of CKD is characterized by cystatin C level of $0.8 \mathrm{mg} / \mathrm{L}$. The prototype was tested at a concentration of $0.00005 \mathrm{mg} / \mathrm{ml}$ of antipain hydrochloride; the residual activity was found to be $97 \%$. At the same concentration of cystatin $\mathrm{C}$, the relative enzymatic activity was $75.3 \%$, which was expected as antipain $\mathrm{HCl}$ is less specific for papain than cystatin C. Similarly, at concentration $0.0005 \mathrm{mg} / \mathrm{ml}$ cystatin C (corresponding to Stage II CKD), the residual activity (for immobilized papain) was $53 \%$, while that for $0.003 \mathrm{mg} / \mathrm{ml}$, the residual activity was about 19\% (Fig. 6). Thus, from the observations, it can be interpreted that a $20 \%$ inhibition in activity of the enzyme immobilized, under given set of conditions, can be direct indication of Stage I CKD and 50\% inhibition indicating Stage II CKD. The change of enzyme activity was easily monitored on the basis of tyrosine equivalents released and subsequent color changes observed.

A further increase in the concentration above $0.008 \mathrm{mg} / \mathrm{ml}$ of inhibitors, the enzymatic activity, was found to almost fully inhibit as no detection was possible. The experimentation confirmed the feasibility of using prototype for detection of cystatin $\mathrm{C}$.

\section{DISCUSSION}

A comparison of the available cystatin C (Siemens, Roche, and Genzyme) assays available in the market is represented in Table $1[20,21]$. The available assays are immunoassay based methods of detection using invasive sample for testing. Presently available kits use antibody based detection, hence are comparatively costly. Moreover, the range of detection is much higher between 0.5 and $5 \mathrm{mg} / \mathrm{ml}$. This high range would mean better specificity and accuracy for cystatin C detection.

Progression of CKD with combination drugs has indicated control at later stages, but identification at stage I and II may facilitate efficient treatment [22,23].

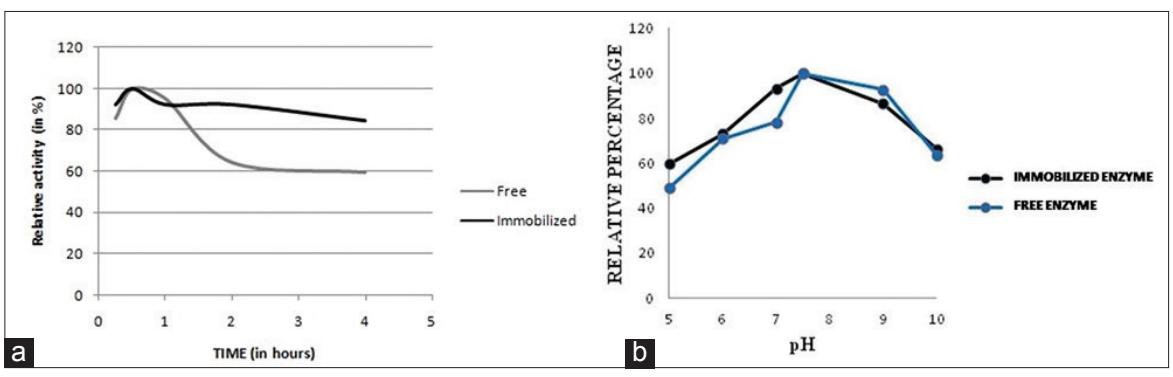

Fig. 4: (a) Shelf stability of free and immobilized enzyme during storage at room temperature, (b) effect of pH on free and immobilized enzyme. The immobilized enzyme has higher functionality at pH 5-5.5 as compared to free enzyme 
Table 1: Comparison of the available cystatin C (Siemens, Roche, and Genzyme) assays available in the market is represented

\begin{tabular}{|c|c|c|c|c|c|}
\hline Type & Method & Set up & $\begin{array}{l}\text { Volume } \\
\text { of sample }\end{array}$ & $\begin{array}{l}\text { Reaction } \\
\text { time (minutes) }\end{array}$ & $\begin{array}{l}\text { Normal } \\
\text { range } \mathrm{mg} / \mathrm{L}\end{array}$ \\
\hline Siemens N-Latex cystatin C & PENIA $^{+}$ & Rabbit antibodies coated polystyrene particles & $30 \mu \mathrm{l}$ & 6 & $0.53-0.95$ \\
\hline Roche-Tina-quant & PENIA & Rabbit antibodies coated polystyrene particles & $2 \mu \mathrm{l}$ & 10 & $0.47-1.09$ \\
\hline Genzyme & PETIA $^{++}$ & Rabbit antibodies coated colloidal gold nanoparticles & $2 \mu \mathrm{l}$ & 10 & $0.61-1.17$ \\
\hline MWCNT-Diagnostic Kit & $\begin{array}{l}\text { Protease } \\
\text { assay }\end{array}$ & $\begin{array}{l}\text { Bioconjugate of papain enzyme immobilized on the } \\
\text { MWCNT-COOH immobilized on a glass slide }\end{array}$ & $1 \mathrm{ml}^{*}$ & $30^{* *}$ & $0.5-5$ \\
\hline
\end{tabular}

MWCNT: Multiwalled carbon nanotube

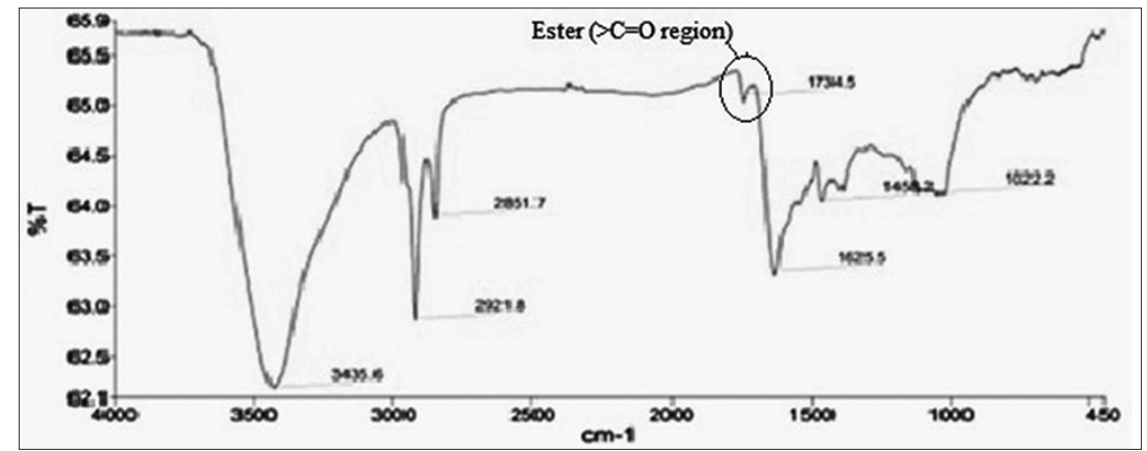

Fig. 5: Fourier transformation infrared graph multiwalled carbon nanotube (MWCNT)/papain: The presence of the ester bond shows the immobilization of papain on MWCNT

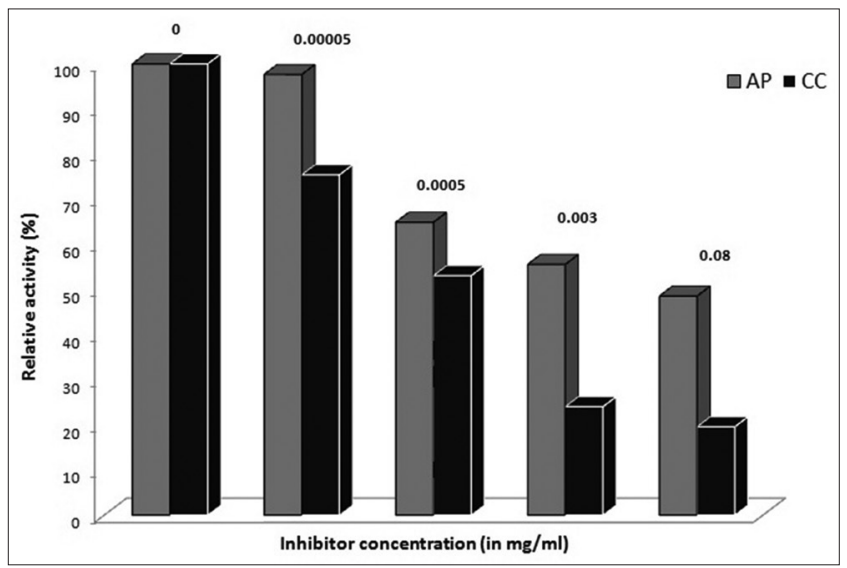

Fig. 6: Effect of protease inhibitors, antipain hydrochloride, and cystatin $C$ on the activity of papain

\section{CONCLUSION}

CKD is usually diagnosed by measuring the rate at which glomeruli filter impurities in the blood, also known as GFR. Most of the diagnostic kits available estimate GFR rate by determining serum creatinine, which is an endogenous substance in the blood that is cleared by the kidney. However, it has been reported that few PIs are also released in the urine during CKD. For example, low molecular weight protein cystatin C is more reliable biomarker for detection of kidney function. Keeping these advantages, a novel versatile prototype diagnostic kit was designed for the detection of CKD based on the principle of interaction between PI (cystatin C) and protease. The prototype thus designed utilizes immobilized papain conjugated with MWCNT, indicates its temperature and $\mathrm{pH}$ stability. The initial design of the diagnostic kit for the detection of CKD has shown to be successful with a good detection range corresponding to Stages I and II of CKD. Further testing needs to be done for the prototype using patient samples.

\section{ACKNOWLEDGMENT}

We would like to acknowledge MRC MNIT, Jaipur, Rajasthan, for conducting the FTIR experiments.

\section{REFERENCES}

1. NHS. Kidney Problems. NHS Choices; 2014. Available from: http:// www.nhs.uk/Livewell/Kidneyhealth/Pages/Theriseofkidneydisease. aspx.

2. Kellum JA, Levin N, Bouman C, Lameire N. Developing a consensus classification system for acute renal failure. Curr Opin Crit Care 2002;8(6):509-14

3. WHO. Global Status Report on Noncommunicable Diseases. Geneva: World Health Organization; 2010.

4. Couser WG, Remuzzi G, Mendis S, Tonelli M. The contribution of chronic kidney disease to the global burden of major noncommunicable diseases. Kidney Int 2011;80(12):1258-70.

5. Veerappan I, Abraham G. Chronic kidney disease: Current status, challenges and management in India. Ch. 130. Section 17. p. 593-7. Available from: http://www.Apiindia.org/medicine_update_2013.

6. WebMD. Chronic Kidney Disease. WebMD Medical Reference from Healthwise. 2013. Available from: http://www.webmd.com/a-to-zguides/chronic-kidney-disease-cause.

7. Fassett RG, Venuthurupalli SK, Gobe GC, Coombes JS, Cooper MA, Hoy WE. Biomarkers in chronic kidney disease: A review. Kidney Int 2011;80(8):806-21.

8. RANDOX Renal Function Test. Available from: http://www.randox. com/brochures/PDF\%20 Brochure/LT031.pdf.RANDOX.

9. Mussap M, Plebani M. Biochemistry and clinical role of human cystatin C. Crit Rev Clin Lab Sci 2004;41(5-6):467-550.

10. Hall YN, Choi AI, Chertow GM, Bindman AB. Chronic kidney disease in the urban poor. Clin J Am Soc Nephrol 2010;5(5):828-35.

11. Qutb A, Syed G, Tamim HM, Al Jondeby M, Jaradat M, Tamimi W, et al. Cystatin C-based formula is superior to MDRD, Cockcroft-Gault and Nankivell formulae in estimating the glomerular filtration rate in renal allografts. Exp Clin Transplant 2009;7(4):197-202.

12. Petrovic S, Bogavac-Stanojevic N, Lakic D, Peco-Antic A, Vulicevic I, Ivanisevic I, et al. Cost-effectiveness analysis of acute kidney injury biomarkers in pediatric cardiac surgery. Biochem Med (Zagreb) 2015;25(2):262-71.

13. Wang Q, Zhou L, Jiang Y, Gao J. Improved stability of the carbon nanotubes-enzyme bioconjugates by biomimetic silicification. Enzyme Microb Technol 2011;49(1):11-6.

14. Hart SR, Waterfield MD, Burlingame AL, Cramer R. Factors governing the solubilization of phosphopeptides retained on ferric NTA IMAC beads and their analysis by MALDI TOFMS. J Am Soc Mass Spectrom 2002;13(9):1042-51.

15. Ding L, Yao Z, Li T, Yue Q, Chai J. Study on papain immobilization on a macroporous polymer carrier. Turk J Chem 2003;27:627-37.

16. Sangeetha K, Abraham TE. Chemical modification of papain for use in 
alkaline medium. J Mol Catal B Enzym 2006;38:171-7.

17. Iwani AK, Mona WZ, Idayu R, Nazaimoon WM. The usefulness of cystatin C as a marker for chronic kidney disease. Univ J Clin Med 2013;1(2):28-33.

18. Benaki DC, Aggeli A, Chryssikos GD, Yiannopoulos YD, Kamitsos EI, Brumley E, et al. Laser-Raman and FT-IR spectroscopic studies of peptide-analogues of silkmoth chorion protein segments. Int J Biol Macromol 1998;23(1):49-59.

19. Nandy SK, Bhuyan R, Seal A. Modelling family 2 cystatins and their interaction with papain. J Biomol Struct Dyn 2013;31(6):649-64.

20. Park MY, Choi SJ, Kim JK, Hwang SD, Lee YW. Urinary cystatin C levels as a diagnostic and prognostic biomarker in patients with acute kidney injury. Nephrology (Carlton) 2013;18(4):256-62.

21. Li J, Dunn W, Breaud A, Elliott D, Sokoll LJ, Clarke W. Analytical performance of 4 automated assays for measurement of cystatin C. Clin Chem 2010;56(8):1336-9.

22. Dasari P, Venkateshwarlu K, Venisetty RK. Management of comorbidities in chronic kidney disease: A prospective observational study. Int J Pharm Pharm Sci 2014;6(2):363-7.

23. Tamilselvan T, Veerapandiyan AK, Karthik N. Study on drug utilization pattern of chronic renal failure patients in a tertiary care hospital. Hypertension 2014;70:112. 